\title{
STABILITY STUDY AND VALIDATED REVERSED PHASE LIQUID CHROMATOGRAPHIC METHOD FOR THE DETERMINATION OF TIROFIBAN HYDROCHLORIDE IN PRESENCE OF TYROSINE AS A PROCESS IMPURITY
}

\author{
RAMZIA I. EL-BAGARY ${ }^{1,2}$, EHAB F. ELKADY ${ }^{2}$, NAIRA A. FARID $^{3 *}$, NADIA F. YOUSSEF ${ }^{3}$ \\ ${ }^{\prime}$ Faculty of Pharmaceutical Sciences and Pharmaceutical Industries, FUE \\ ${ }^{2}$ Pharmaceutical Chemistry Department, Faculty of Pharmacy, Cairo University, Kasr El-Aini St., Cairo 11562, Egypt \\ ${ }^{3}$ National organization for Drug Control and Research (NODCAR), Giza, Egypt
}

\begin{abstract}
Tirofiban hydrochloride was subjected to the degradation under conditions of hydrolysis (acidic and alkaline degradation), oxidative, thermal and photolytic degradation as prescribed by ICH. A simple and precise liquid chromatographic method has been developed and validated for the simultaneous determination of tirofiban hydrochloride monohydrate (TIR) and its synthetic starting material; tyrosine (TRS). All the chromatographic separations were achieved on Zorbax $\mathrm{SB} C 18,250 \mathrm{~mm} \times 4.6 \mathrm{~mm}$ i.d., $5 \mu \mathrm{m}$ column at a flow rate of $1 \mathrm{~mL} \mathrm{~min}^{-1}$. Isocratic elution based on $0.1 \mathrm{M}$ phosphate buffer (pH 3) - acetonitrile (70:30, $\left.v / v\right)$ with UV detection at $227 \mathrm{~nm}$ was applied. For the stability study separation of TIR from its degradation products was achieved using $0.1 \mathrm{M}$ phosphate buffer (pH 3) acetonitrile $(72: 28, v / v)$ with UV detection at $210 \mathrm{~nm}$. Method validation parameters namely, linearity, accuracy and precision were found to be acceptable over the concentration ranges of $10-250 \mu \mathrm{g} \mathrm{mL}^{-1}$ for TIR and $1-70 \mu \mathrm{g} \mathrm{mL}^{-1}$ for TRS. The minimum detection limits were $1.76 \mu \mathrm{g} \mathrm{mL}^{-1}$ for TIR and $0.13 \mu \mathrm{g} \mathrm{mL}-1$ for TRS. The optimized method was validated and proved to be specific, robust and accurate for the quality control of the cited drug in drug substance and drug product.
\end{abstract}

Keywords: Stability study; Tirofiban hydrochloride monohydrate; Tyrosine; Reversed-phase liquid chromatography; Method validation; Intravenous infusion.

\section{INTRODUCTION}

Tirofiban hydrochloride monohydrate (TIR), a non-peptide molecule, is chemically described as $\mathrm{N}$ (butylsulfonyl)-O-[4-(4-piperidinyl) butyl]L-tyrosine monohydrochloride monohydrate (Figure 1). TIR is a fibrinogenreceptor antagonist which inhibits platelet aggregation by competitively binding to membrane-bound glycoprotein complex GPIIb/IIIa on the surface of activated platelets, preventing the binding of fibrinogen [1].

L-Tyrosine (TRS), L-2-Amino-3-(4-hydroxyphenyl) propionic acid (Figure 1). It is an aromatic non-essential amino acid. It is used as a dietary supplement [2]. It is a synthetic starting material of tirofiban [3].<smiles>NC(Cc1ccc(O)cc1)C(=O)O</smiles>

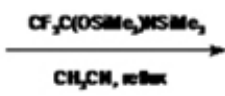

Tyrosine
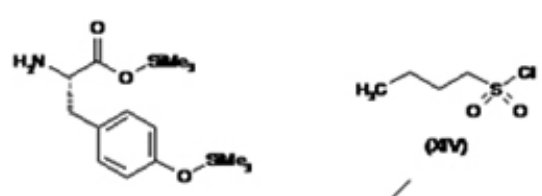

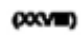
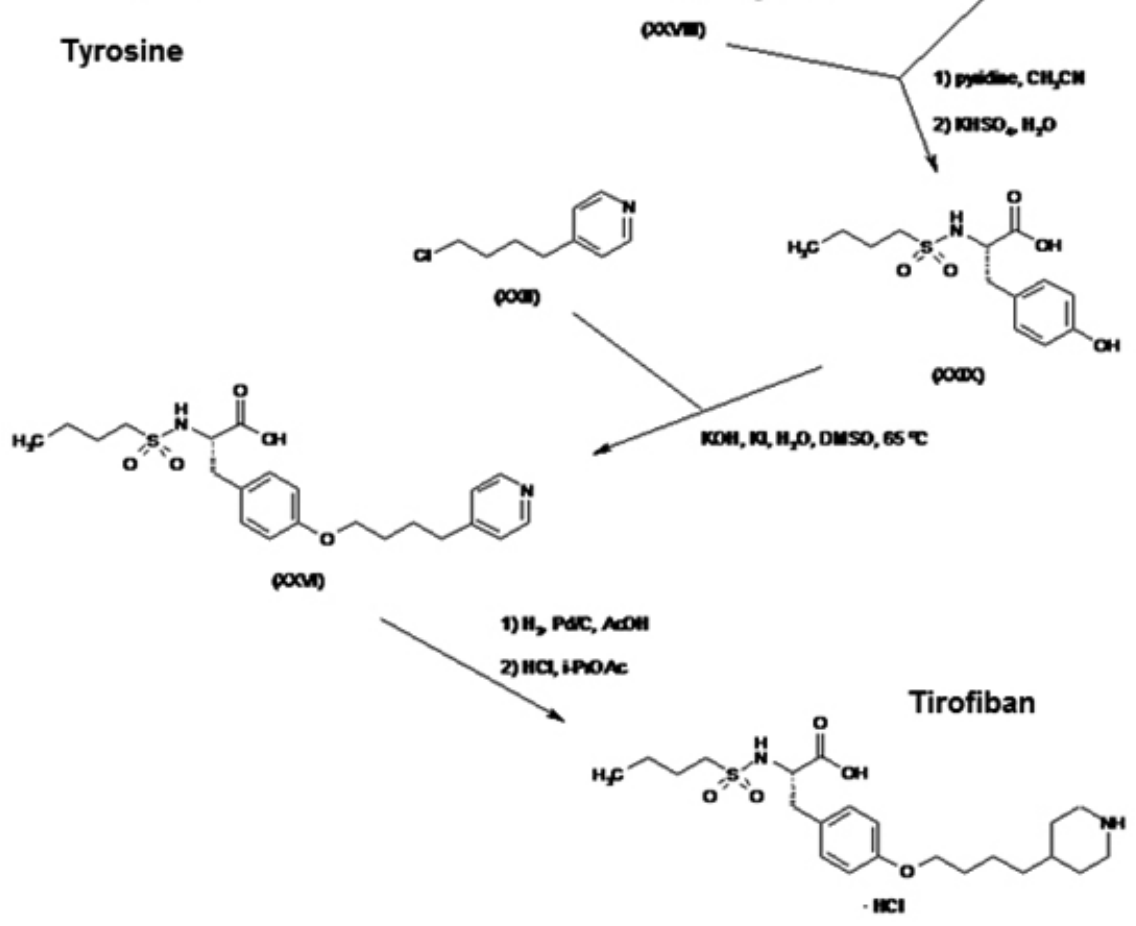

Figure 1: The synthesis of TIR from TRS. 
TIR is non official drug in any pharmacopeia.

Several analytical methods have been described in literature for the determination of TIR in bulk, pharmaceutical and biological samples. These methods include UV spectrophotometry [4, 5], HPLC [5-9], LC-MS [10, 11] and TLC [5].

Novality of this work that, no stability study on TIR was reported before and due to the lack of reported LC methods describing determination of TIR in presence of its synthetic starting material TRS which is expected to be an in-process impurity (Figure 1). The present stability testing shows that tyrosine is one of the degradants. It was deemed useful to develop simple, sensitive, validated and selective LC method for the simultaneous determination of TIR and TRS. The proposed method was designed to be suitable for the quality assessment of TIR in drug substance and pharmaceutical preparations.

\section{EXPERIMENTAL}

\section{Instrumentation}

The HPLC (Agilent 1100 series-Germany) system was equipped with G1311A isocratic pump, UV-visible G1314A detector and a manual injector equipped with $(20 \mu \mathrm{l})$ injector loop. Data was processed with HPCORE chemstation. Separation and quantitation were carried out on Zorbax SB C-18, $250 \mathrm{~mm} \times 4.6 \mathrm{~mm}$ i.d., $5 \mu \mathrm{m}$ (Agilent,Germany) maintained at ambient temperature. An Elma ultrasonic processor (Germany) was used. A sidebench Ecocell 55 oven $250^{\circ} \mathrm{C}$ (München, Germany) was used to control the temperature during stability study. Jenway 3510 (Staffordshire, UK) was used to adjust the $\mathrm{pH}$. Vilber Lourmat UV lamp was used for the photo-degradation.

Reagents and reference samples

Pharmaceutical grade TIR, certified to contain $102.92 \%$, was supplied by Gland chemical private LTD (Egypt) and L-TRS, certified to contain $\geq 98 \%$, was supplied and manufactured by Sigma-Aldrich (Germany). Aggrastat $\mathbb{R}$ intravenous infusion was manufactured by Algorithm and supplied as a sterile solution in water for injection. Each $100 \mathrm{~mL}$ of the premixed, iso-osmotic intravenous injection contains $5.618 \mathrm{mg}$ of TIR HCL equivalent to $5 \mathrm{mg}$ tirofiban $\left(50 \mu \mathrm{g} \mathrm{mL}^{-1}\right)$, sodium chloride, sodium citrate dihydrate and citric acid anhydrous. HPLC grade acetonitrile, methanol and hydrochloric acid were supplied by Sigma-Aldrich (Germany). Reagent grade sodium hydroxide, potassium dihydrogen ortho phosphate and hydrogen peroxide were supplied by El Nasar Company. Bi-distilled water was produced in-house (Aquatron Water Still, A4000D, UK). Membrane filters, $0.45 \mu \mathrm{m}$ (Teknokroma, Barcelona, Spain), were used.

Chromatographic conditions

Chromatographic separation was achieved on a Zorbax SB C-18 column $(250 \mathrm{~mm} \times 4.6 \mathrm{~mm}, 5 \mu \mathrm{m})$ applying an isocratic elution based on a mobile phase consisting of $0.1 \mathrm{M}$ phosphate buffer $(\mathrm{pH} 3)$ - acetonitrile $(70: 30, v / v)$ and $(72: 28, v / v)$ for the stability study. The buffer solution was filtered through $0.45 \mu \mathrm{m}$ membrane filter and degassed for $15 \mathrm{~min}$ in an ultrasonic bath prior to its use. The mobile phase was pumped through the column at a flow rate of 1 $\mathrm{mL} \mathrm{min}{ }^{-1}$. Analyses of all samples were performed at ambient temperature and detection was carried out at $227 \mathrm{~nm}$ for TIR and TRS and at $210 \mathrm{~nm}$ for the degradation products. The injection volume was $20 \mu \mathrm{L}$.

\section{Stock standard solutions preparation}

Standard stock solutions of TIR and TRS $\left(1.0 \mathrm{mg} \mathrm{mL}^{-1}\right)$ were prepared by separately dissolving $100 \mathrm{mg}$ of the two compounds in the mobile phase in two $100-\mathrm{mL}$ volumetric flasks, sonicated and completed to volume with the same solvent. Further dilution was carried out to obtain solutions of $\left(500 \mu \mathrm{g} \mathrm{mL}^{-1}\right)$ and $\left(100 \mu \mathrm{g} \mathrm{mL}^{-1}\right)$ for TIR and TRS, respectively. The required concentrations were prepared by serial dilutions.

\section{Stress degradation condition}

1. Acid and base degradation

$25 \mathrm{mg}$ of TIR was seperately dissolved in $25 \mathrm{ml}$ of $0.1,0.5$ and $1 \mathrm{M}$ $\mathrm{NaOH}$ or $\mathrm{HCl}$. The mixtures were kept at room temperature for $8 \mathrm{~h}$. The stress degradation in acidic and basic media was performed in the dark in order to exclude the possible degradative effect of light. These experiments were repeated by refluxing at temperature of $75^{\circ} \mathrm{C}$ for 30 minutes while keeping all other conditions constant. Each solution $\left(1 \mathrm{mg} \mathrm{mL}^{-1}\right)$ was neutralized using the corresponding molarity of $\mathrm{HCl}$ and $\mathrm{NaOH}$. Twenty microliters of the resultant solutions were injected onto column and the chromatograms were run as described in"Chromatographic Conditions".

\section{Oxidative Degradation}

$25 \mathrm{mg}$ of TIR was seperately dissolved in $25 \mathrm{ml}$ of $3 \%$ and $15 \% \mathrm{H}_{2} \mathrm{O}_{2}$. The prepared mixtures were kept at room temperature for 12 and $5 \mathrm{~h}$, respectively. Each solution was evaporated to dryness using waterbath and dissolved in the mobile phase $\left(1 \mathrm{mg} \mathrm{mL}^{-1}\right)$. Twenty microliters of the resultant solutions were injected onto column and the chromatograms were run as described
in"Chromatographic Conditions".

3. Thermal and Photolytic Degradation

The dry powder of the drug was placed in oven at $55^{\circ} \mathrm{C}$ for $72 \mathrm{~h}$ to study dry heat degradation. The photochemical stability of the drug was also studied by exposing the dry powder to UV lamp for $48 \mathrm{~h}$. Powder was dissolved and diluted with the mobile phase $\left(0.25 \mathrm{mg} \mathrm{mL}^{-1}\right)$. Twenty microliters of the resultant solutions were injected onto column and the chromatograms were run as described in"Chromatographic Conditions".

All samples of stability testing were assessed by RP-LC on Zorbax SB $\mathrm{C} 18,250 \mathrm{~mm} \times 4.6 \mathrm{~mm}$ i.d., $5 \mu \mathrm{m}$ column at a flow rate of $1 \mathrm{~mL} \mathrm{~min}{ }^{-1}$ using 0.1 $\mathrm{M}$ phosphate buffer $(\mathrm{pH} 3)$ - acetonitrile $(72: 28, v / v)$ with UV detection at 210 $\mathrm{nm}$ with retention time $9.7 \pm 0.4$ minute.

\section{Procedure}

Accurately measured aliquots of stock standard solutions $\left(500 \mu \mathrm{g} \mathrm{mL}^{-1}\right)$ and $\left(100 \mu \mathrm{g} \mathrm{mL}^{-1}\right)$ for TIR and TRS, respectively were separately transferred into two series of $10 \mathrm{~mL}$ volumetric flasks and completed to volume with mobile phase to prepare solutions (10-250 $\left.\mu \mathrm{g} \mathrm{mL}^{-1}\right)$ of TIR and (1-70 $\mu \mathrm{g} \mathrm{mL}$ ${ }^{-1}$ ) of TRS. A volume of $20 \mu \mathrm{L}$ of each solution was injected in triplicates into the chromatograph. The conditions including the mobile phase at a flow rate $1 \mathrm{~mL} \mathrm{~min}-1$ and detection at $227 \mathrm{~nm}$ were applied. A calibration curve for each compound was obtained by plotting areas under the peaks against concentrations.

Assay of laboratory prepared mixtures

The procedure mentioned above was repeated using laboratory prepared mixtures solutions of (40-250 $\left.\mu \mathrm{g} \mathrm{mL}^{-1}\right)$ for TIR and $\left(2.5-10 \mu \mathrm{g} \mathrm{mL}^{-1}\right)$ for TRS.

Assay of Aggrastst ${ }^{\circledR}$ intravenous infusion

Different aliquots of aggrastat ${ }^{\circledR}$ infusion $\left(11.236-44.944 \mu \mathrm{g} \mathrm{mL}^{-1}\right)$ were analyzed using the mentioned chromatographic conditions.

\section{RESULTS AND DISCUSSION}

The aim of the work was to study the stability of TIR under stress conditions.

Sability testing of TIR

\section{Acid- and Base-Induced Degradation}

The chromatograms of the alkaline-degraded samples of TIR using 0.1 , $0.5,1 \mathrm{M} \mathrm{NaOH}$ either on cold or by heating at $75^{\circ} \mathrm{C}$ for $30 \mathrm{~min}$, showed partial degradation of the intact drug from 6-53\% (Figures 2, 3). Also, exposing the intact drug to $0.1,0.5,1 \mathrm{M} \mathrm{HCl}$, using the previous conditions, led to significant degradation of the drug (7-45\%) (Figures 4, 5). The figures reflect the partial stability of TIR to acidic or alkaline hydrolysis showing that the peaks of degraded products were well resolved from the drug peak and the results are shown in Table 1.

Table 1. Results of stress degradation study for TIR

\begin{tabular}{|c|c|c|c|}
\hline $\begin{array}{l}\text { Stress degradation } \\
\text { conditions }\end{array}$ & Temperature & Time & $\begin{array}{c}\text { Percentage } \\
\text { degradation }(\%)\end{array}$ \\
\hline $\begin{array}{c}\text { Base hydrolysis } \\
\text { On cold } \\
0.1 \mathrm{~N} \mathrm{NaoH} \\
0.5 \mathrm{~N} \mathrm{NaoH} \\
1 \mathrm{~N} \mathrm{NaoH} \\
\text { With reflux } \\
0.1 \mathrm{~N} \mathrm{NaoH} \\
0.5 \mathrm{~N} \mathrm{NaoH} \\
1 \mathrm{~N} \mathrm{NaoH}\end{array}$ & $\begin{array}{l}25^{\circ} \mathrm{C} \\
25^{\circ} \mathrm{C} \\
25^{\circ} \mathrm{C} \\
75^{\circ} \mathrm{C} \\
75^{\circ} \mathrm{C} \\
75^{\circ} \mathrm{C}\end{array}$ & $\begin{array}{l}8 \mathrm{hr} \\
8 \mathrm{hr} \\
8 \mathrm{hr} \\
30 \mathrm{~min} \\
30 \mathrm{~min} \\
30 \mathrm{~min}\end{array}$ & $\begin{array}{c}6 \% \\
35 \% \\
53 \% \\
\\
5 \% \\
26 \% \\
35 \%\end{array}$ \\
\hline $\begin{array}{c}\text { Acid hydrolysis } \\
\text { On cold } \\
0.1 \mathrm{~N} \mathrm{Hcl} \\
0.5 \mathrm{~N} \mathrm{Hcl} \\
1 \mathrm{~N} \mathrm{Hcl} \\
\text { With reflux } \\
0.1 \mathrm{~N} \mathrm{Hcl} \\
0.5 \mathrm{~N} \mathrm{Hcl} \\
1 \mathrm{~N} \mathrm{Hcl}\end{array}$ & $\begin{array}{l}25^{\circ} \mathrm{C} \\
25^{\circ} \mathrm{C} \\
25^{\circ} \mathrm{C} \\
75^{\circ} \mathrm{C} \\
75^{\circ} \mathrm{C} \\
75^{\circ} \mathrm{C}\end{array}$ & $\begin{array}{l}8 \mathrm{hr} \\
8 \mathrm{hr} \\
8 \mathrm{hr} \\
30 \mathrm{~min} \\
30 \mathrm{~min} \\
30 \mathrm{~min}\end{array}$ & $\begin{array}{c}12 \% \\
25 \% \\
45 \% \\
\\
7 \% \\
27 \% \\
28 \%\end{array}$ \\
\hline $\begin{array}{l}\text { Oxidation } \\
3 \% \mathrm{H}_{2} \mathrm{O}_{2} \\
15 \% \mathrm{H}_{2} \mathrm{O}_{2}\end{array}$ & $\begin{array}{l}25^{\circ} \mathrm{C} \\
25^{\circ} \mathrm{C}\end{array}$ & $\begin{array}{l}12 \mathrm{hr} \\
5 \mathrm{hr}\end{array}$ & $\begin{array}{l}51.7 \% \\
51.1 \% \\
\end{array}$ \\
\hline Dry Heating & $55^{\circ} \mathrm{C}$ & $72 \mathrm{hr}$ & $1.3 \%$ \\
\hline Photo stability & $25^{\circ} \mathrm{C}$ & $48 \mathrm{hr}$ & $10.9 \%$ \\
\hline
\end{tabular}


a)

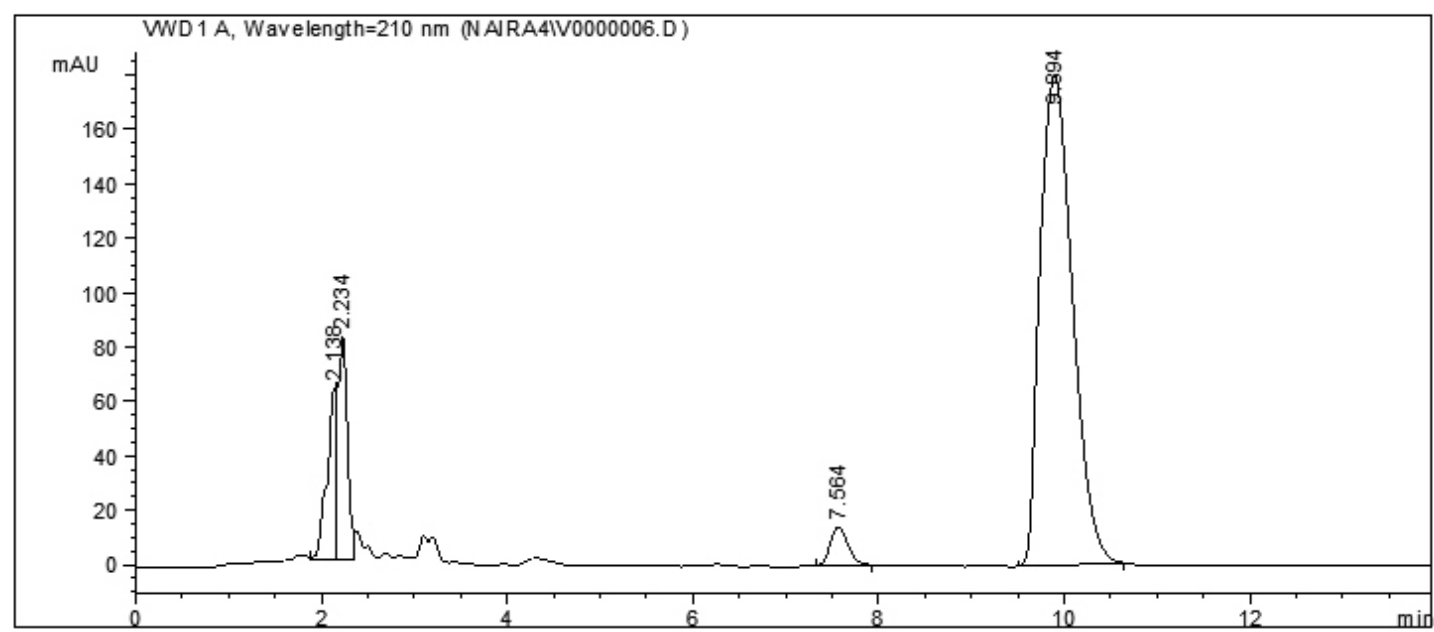

b)

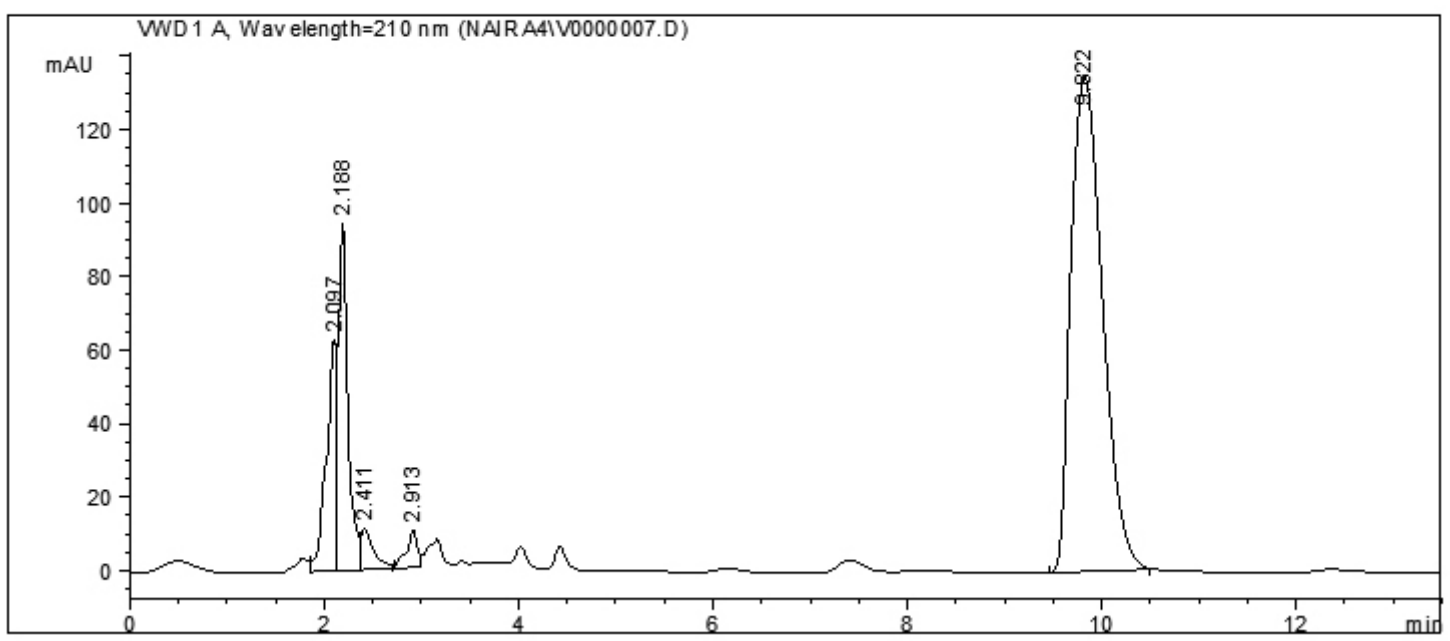

c)

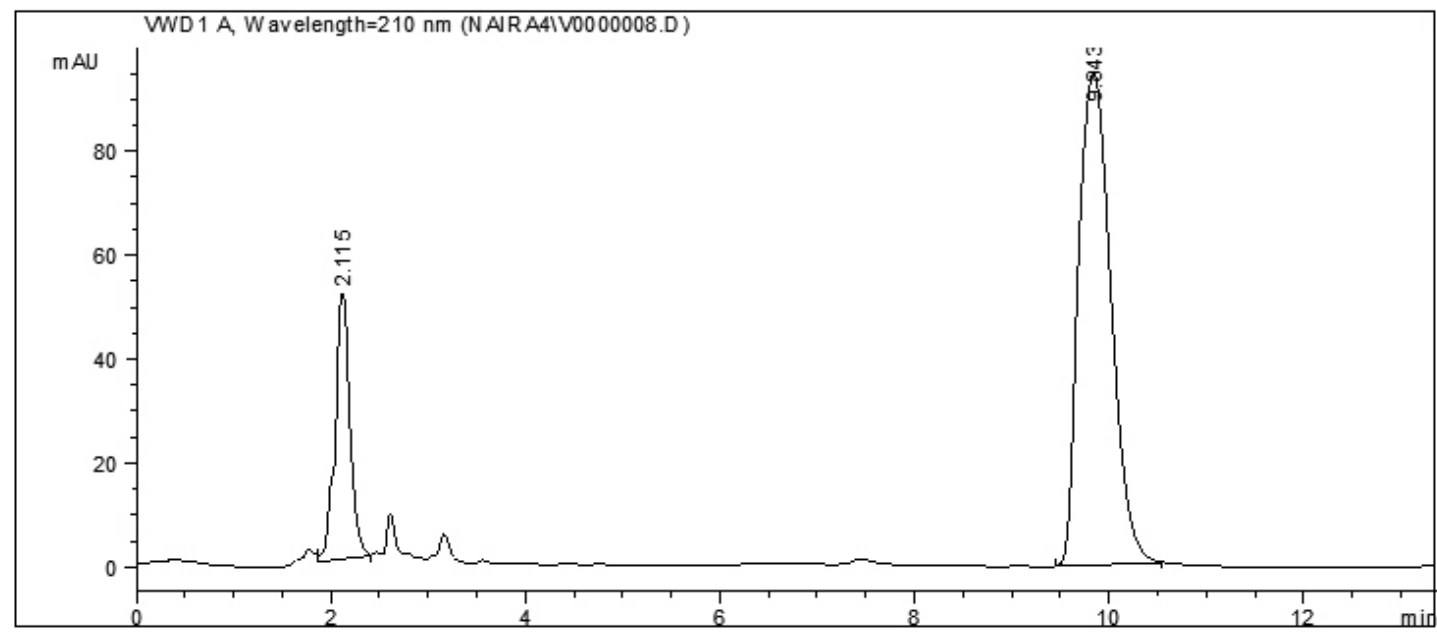

Figure 2: Chromatograms of stress degradation with a) 0.1 b) 0.5 and c) $1 \mathrm{~N} \mathrm{NaOH}$ on cold. 
a)

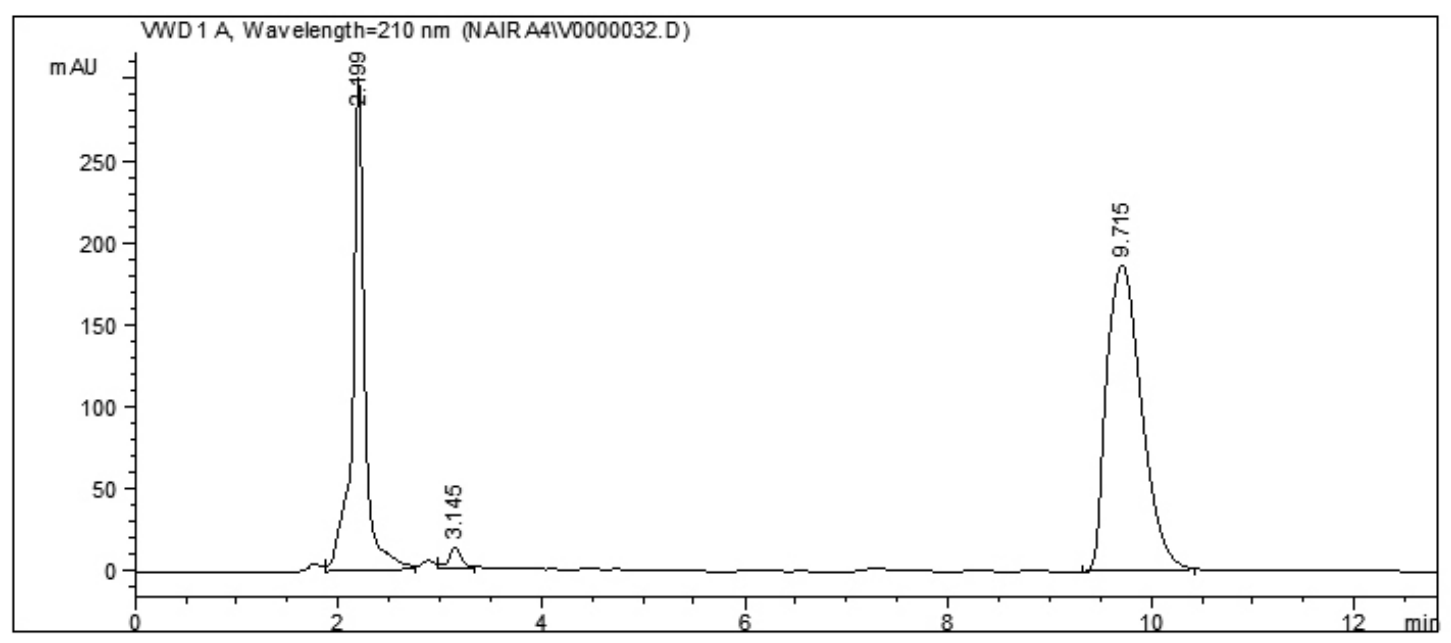

b)

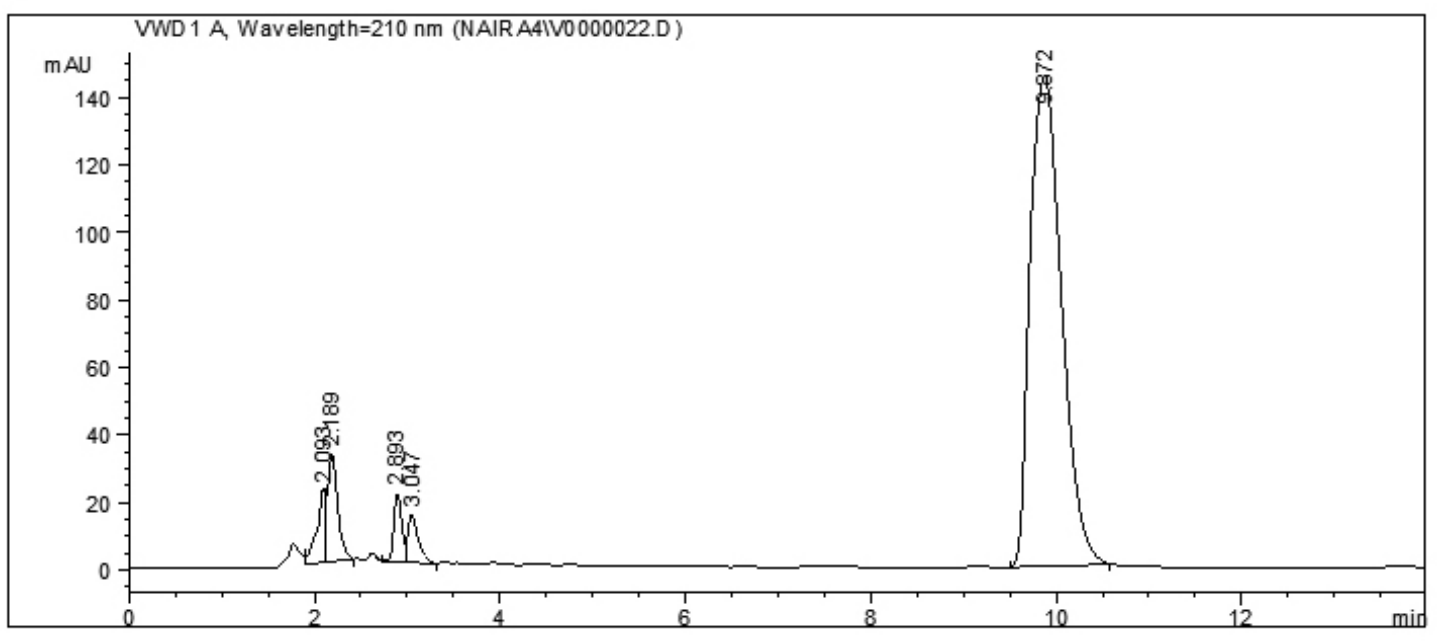

c)

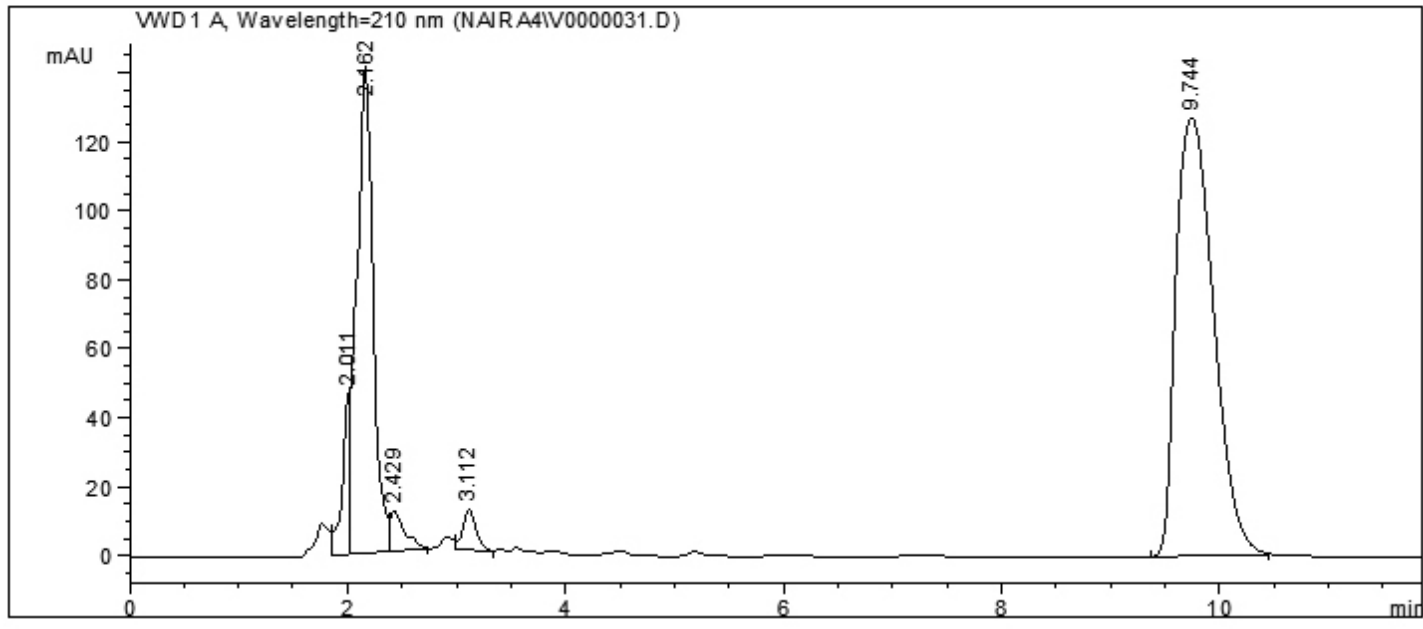

Figure 3: Chromatograms of stress degradation with a) 0.1 b) 0.5 and c) $1 \mathrm{~N} \mathrm{NaOH}$ with reflux 
a)

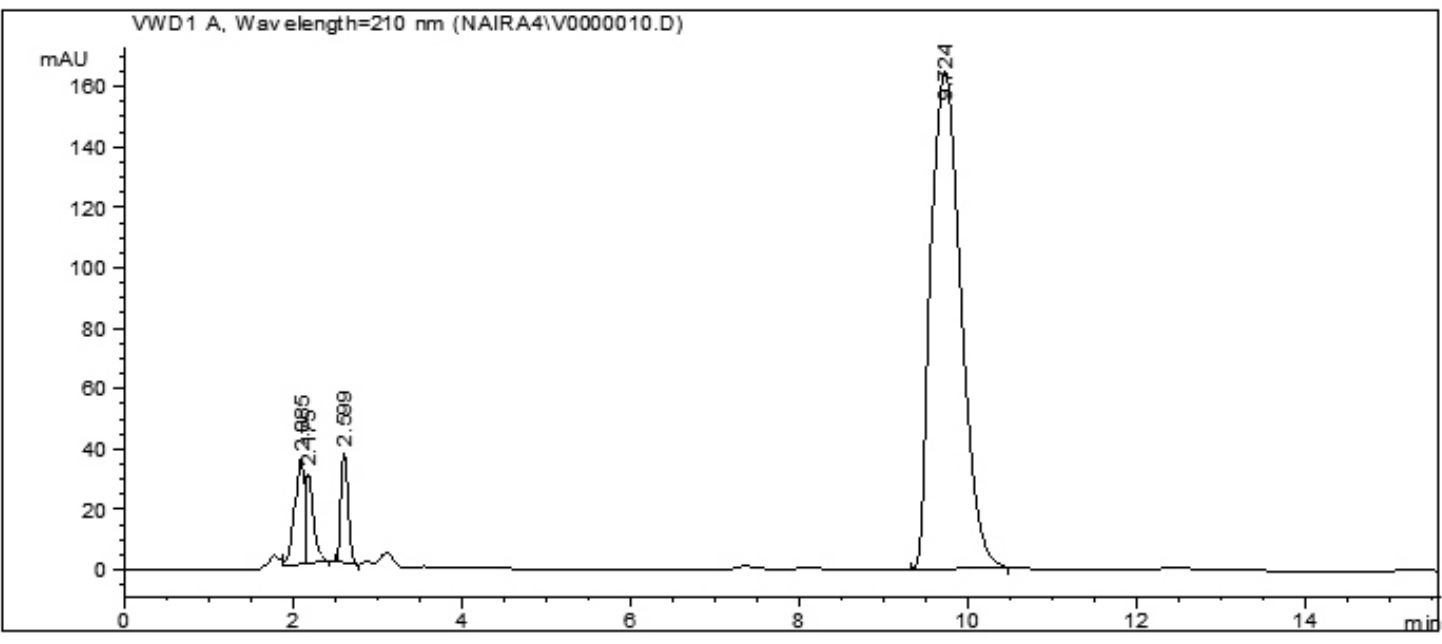

b)

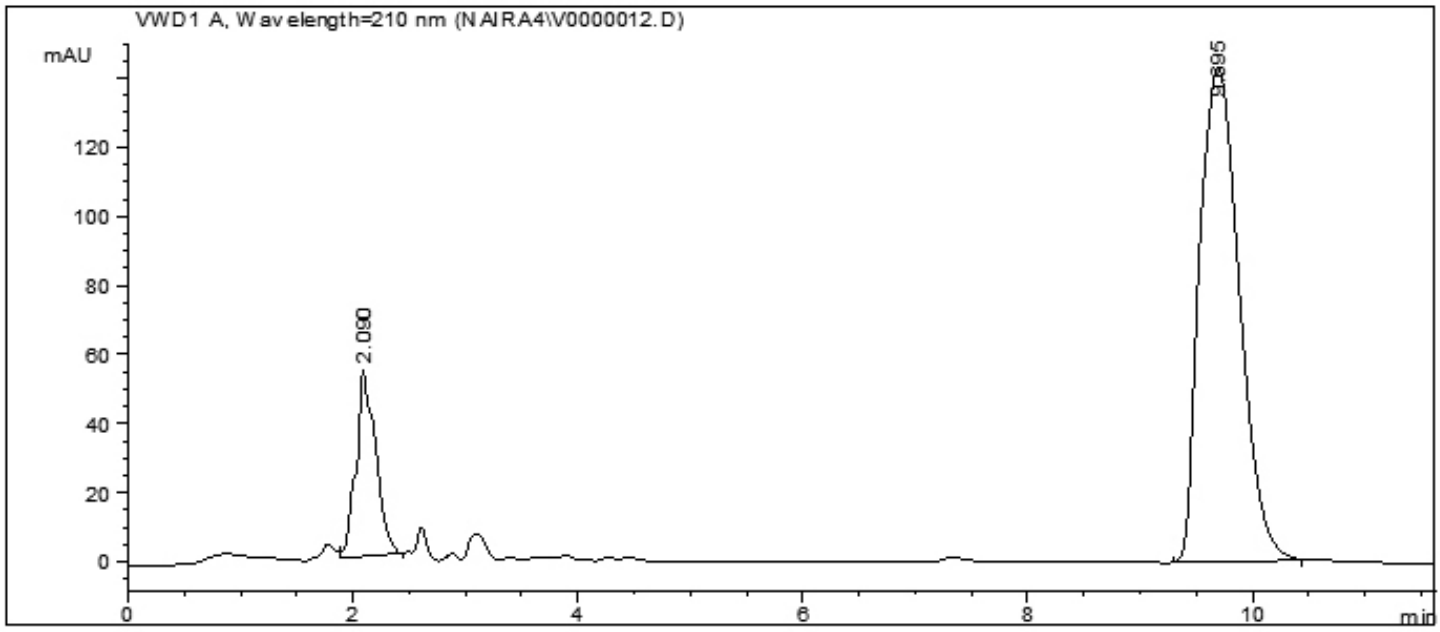

c)

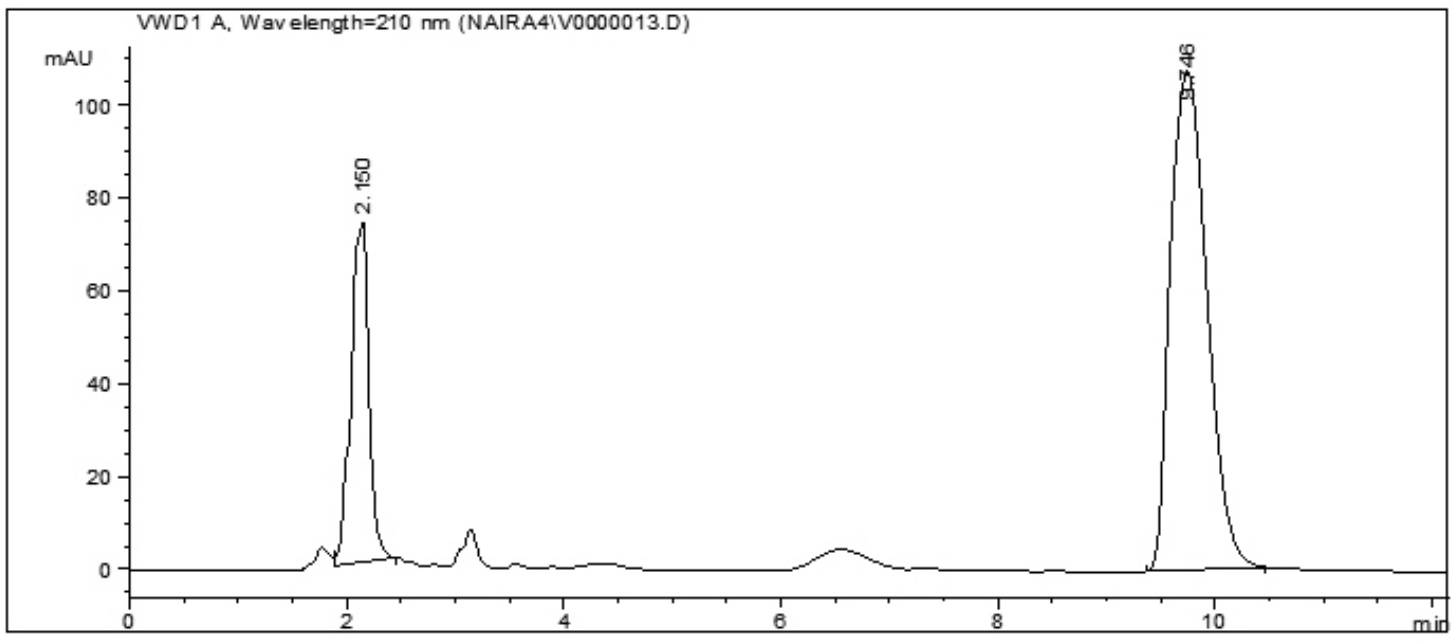

Figure 4: Chromatograms of stress degradation with a) 0.1 b) 0.5 and c) $1 \mathrm{~N} \mathrm{HCl}$ on cold. 
a)

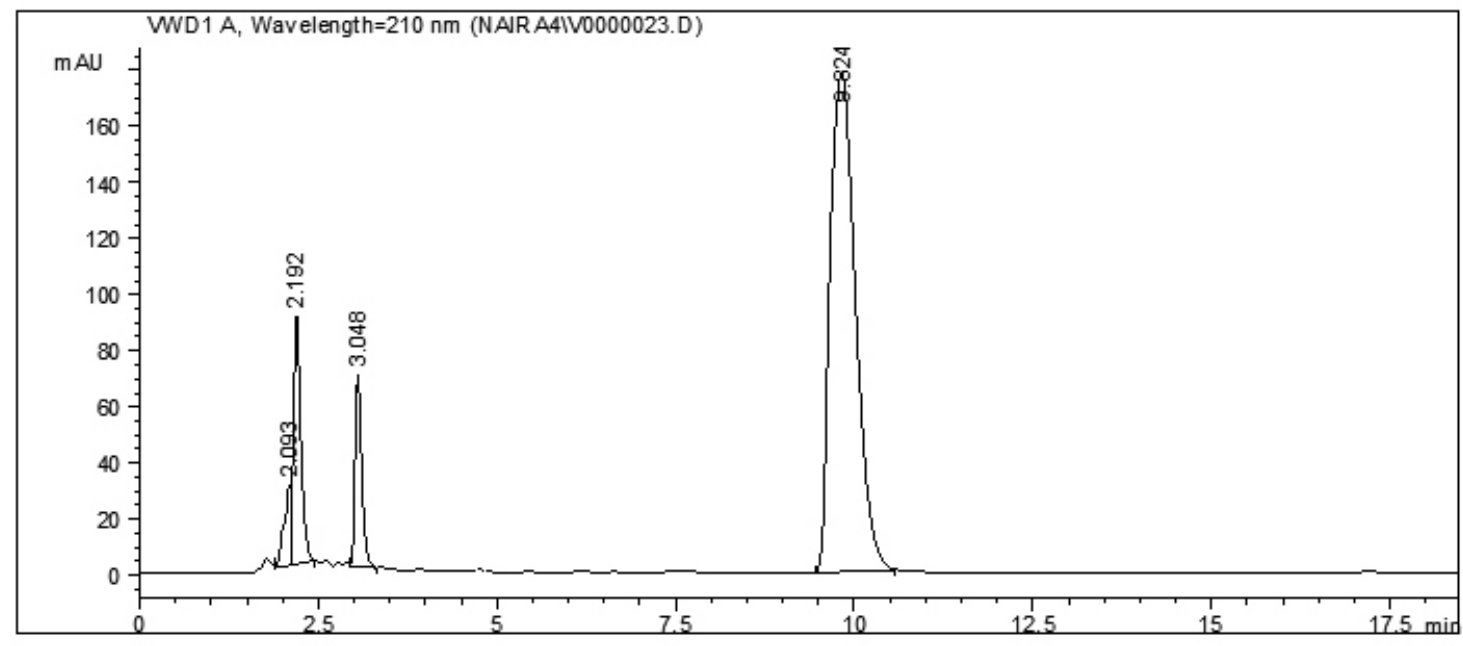

b)

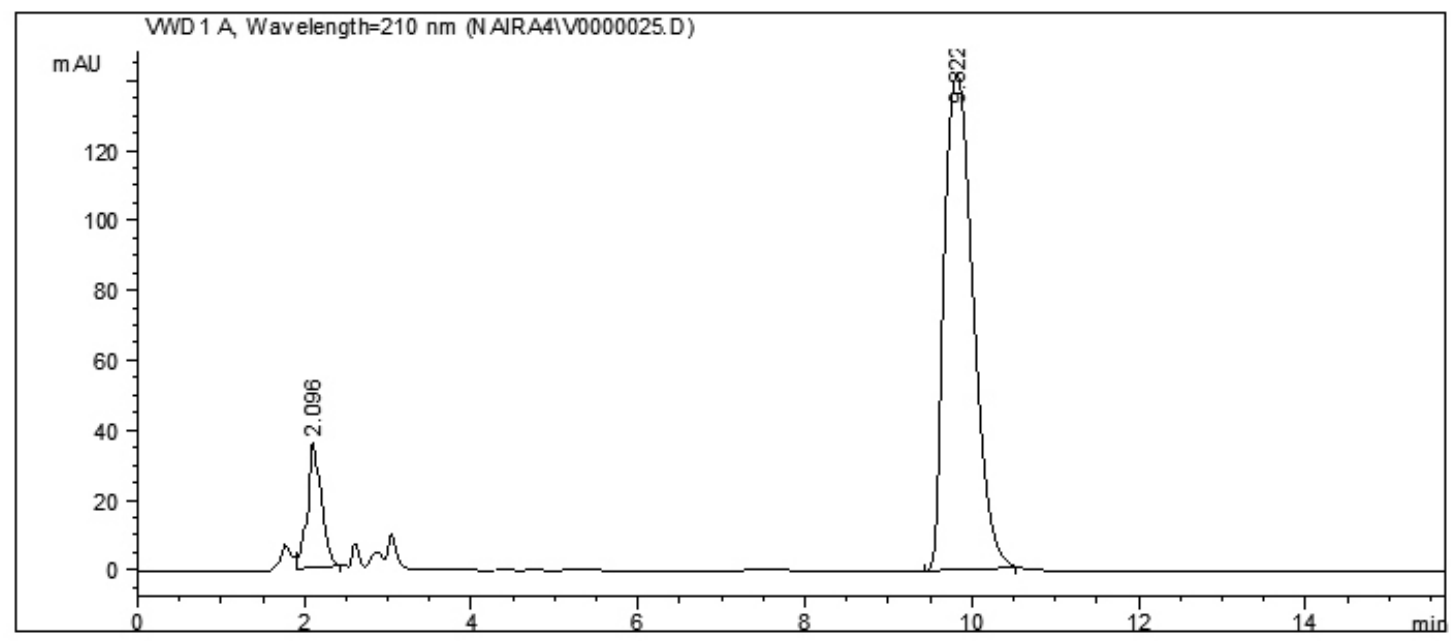

c)

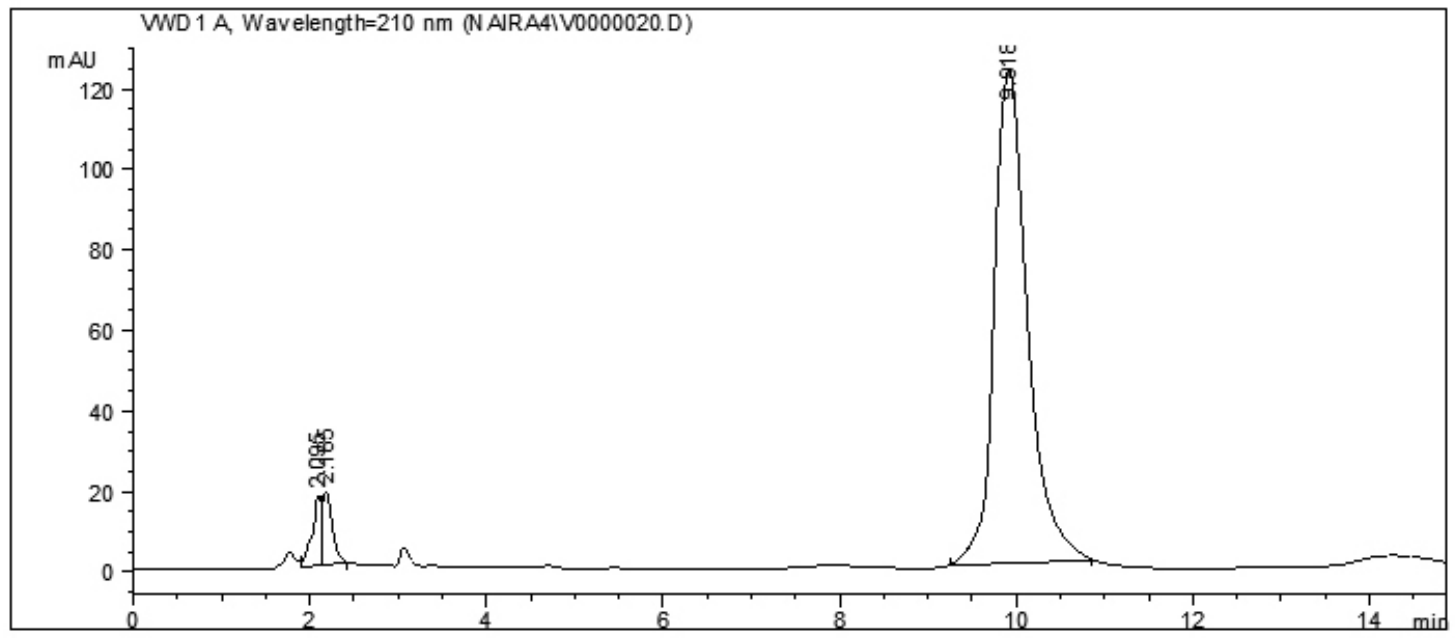

Figure 5: Chromatograms of stress degradation with a) 0.1 b) 0.5 and c) $1 \mathrm{~N} \mathrm{HCl}$ with reflux 


\section{Oxidative degradation}

Nearly equal degradation of TIR was observed when exposed to $3 \%$ and $15 \% \mathrm{H}_{2} \mathrm{O}_{2}$, respectively (Figures $6 \mathrm{a}$, 6b). The percentages of degradation are shown in Table 1.

a)

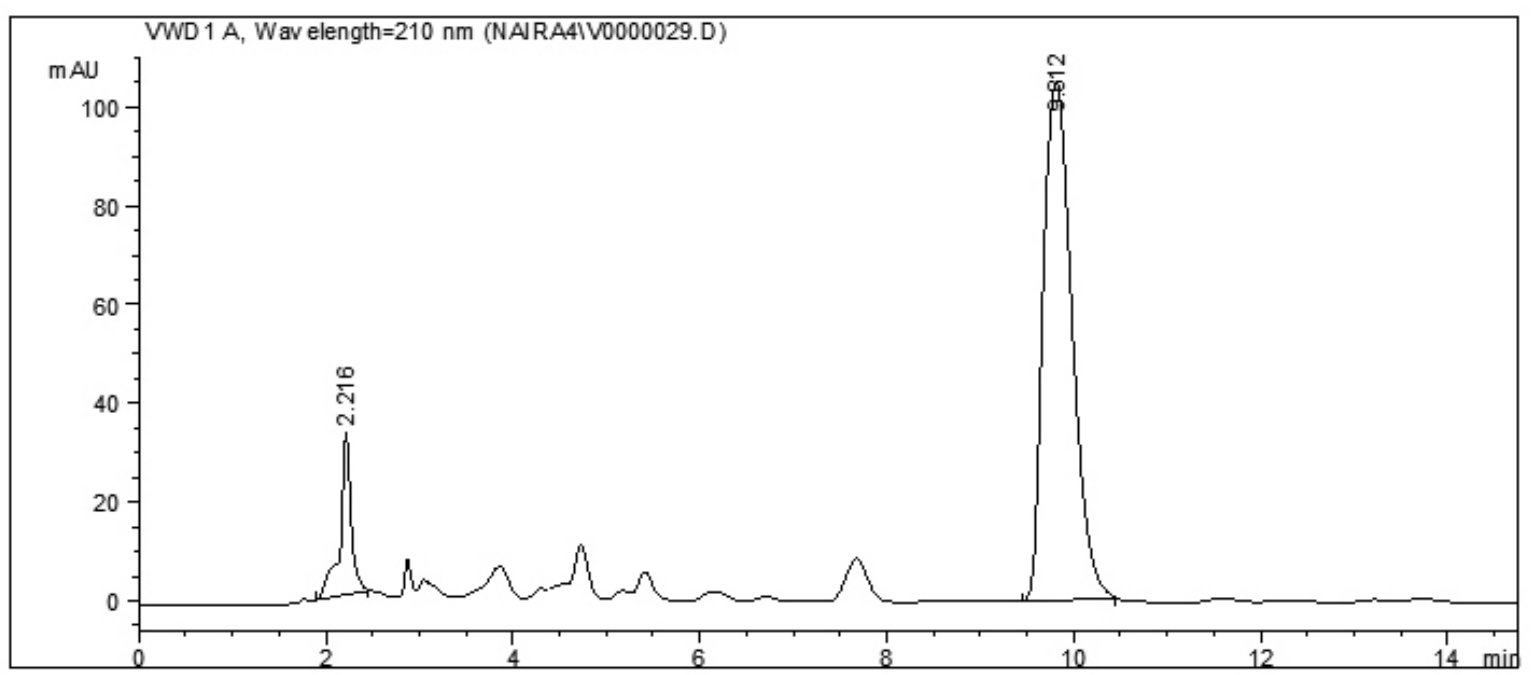

b)

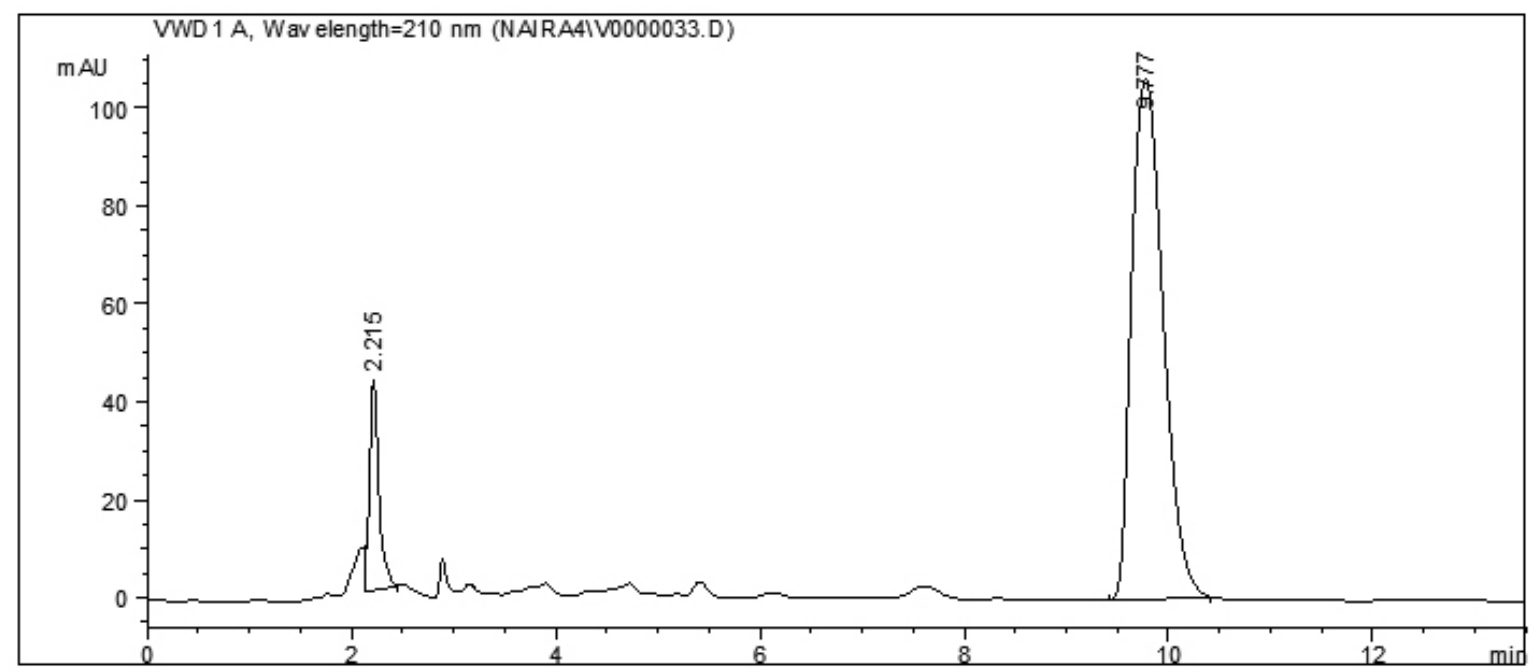

Figure 6: Chromatograms of stress degradation with a) $3 \% \mathrm{H}_{2} \mathrm{O}_{2}$ and b) $15 \% \mathrm{H}_{2} \mathrm{O}_{2}$.

\section{Dry heat and Photo- degradation}

Mild degradation of TIR was occurred when heated at $55^{\circ} \mathrm{C}$ for $72 \mathrm{hr}$ and when exposed to UV light for $48 \mathrm{hr}$ (Figures 7, 8). The percentages of degradation are shown in Table 1.

\section{Method development}

In order to achieve simultaneous elution and separation of the two compounds TIR and TRS, different chromatographic conditions were attempted. So, various mobile phase compositions like methanol with $0.1 \mathrm{M}$ phosphate buffer, or acetonitrile with methanol and $0.1 \mathrm{M}$ phosphate buffer, in different proportions, were tried in an isocratic mode. Different $\mathrm{pH}$ values were attempted including $\mathrm{pH} 3, \mathrm{pH} 5$ and $\mathrm{pH} 8$. Optimum separation of the two compounds with good peak shapes was obtained by applying a mobile phase consisting of $0.1 \mathrm{M}$ phosphate buffer $(\mathrm{pH} 3)$ - acetonitrile $(70: 30, v / v)$ at a flow rate $1 \mathrm{~mL} \mathrm{~min}^{-1}$. Detection was carried out at $227 \mathrm{~nm}$ for TIR and TRS where high detector sensitivity was achieved. The retention times were $2.19 \pm 0.06$ and $7.01 \mathrm{~min} \pm 0.07$ for TRS and TIR respectively; as presented in Figure 9.

\section{Method validation}

\section{Linearity}

The linearity of the RP- LC methods for the determination of the mixture was evaluated. A linear relationship between area under the peak and component concentration was obtained. The regression equation $(\mathrm{y}=\mathrm{b} \mathrm{C} \pm \mathrm{a})$ for each mixture component was also computed. According to the International Conference on Harmonization [12], at least five concentrations must be used. In this study, ten concentrations $(10,30,40,50,60,90,110,150,210$ and $\left.250 \mu \mathrm{g} \mathrm{mL}^{-1}\right)$ from stock solution $\left(500 \mu \mathrm{g} \mathrm{mL}^{-1}\right)$ were chosen for TIR and nine concentrations $\left(1,10,20,30,35,40,50,60\right.$ and $\left.70 \mu \mathrm{g} \mathrm{mL}^{-1}\right)$ from stock solution $\left(100 \mu \mathrm{g} \mathrm{mL}^{-1}\right)$ were chosen for TRS. Each concentration was injected three times. The linearity of the calibration curves was validated by the high value of correlation coefficients (greater than 0.99 for the two compounds). The analytical regression data of the calibration curve of each drug are summarized in Table 2. The linear calibration plot for the two compounds was also determined over the calibration ranges $10-250 \mu \mathrm{g} \mathrm{mL}^{-1}$ and $1-70 \mu \mathrm{g} \mathrm{mL}$ for TIR and TRS, respectively. 


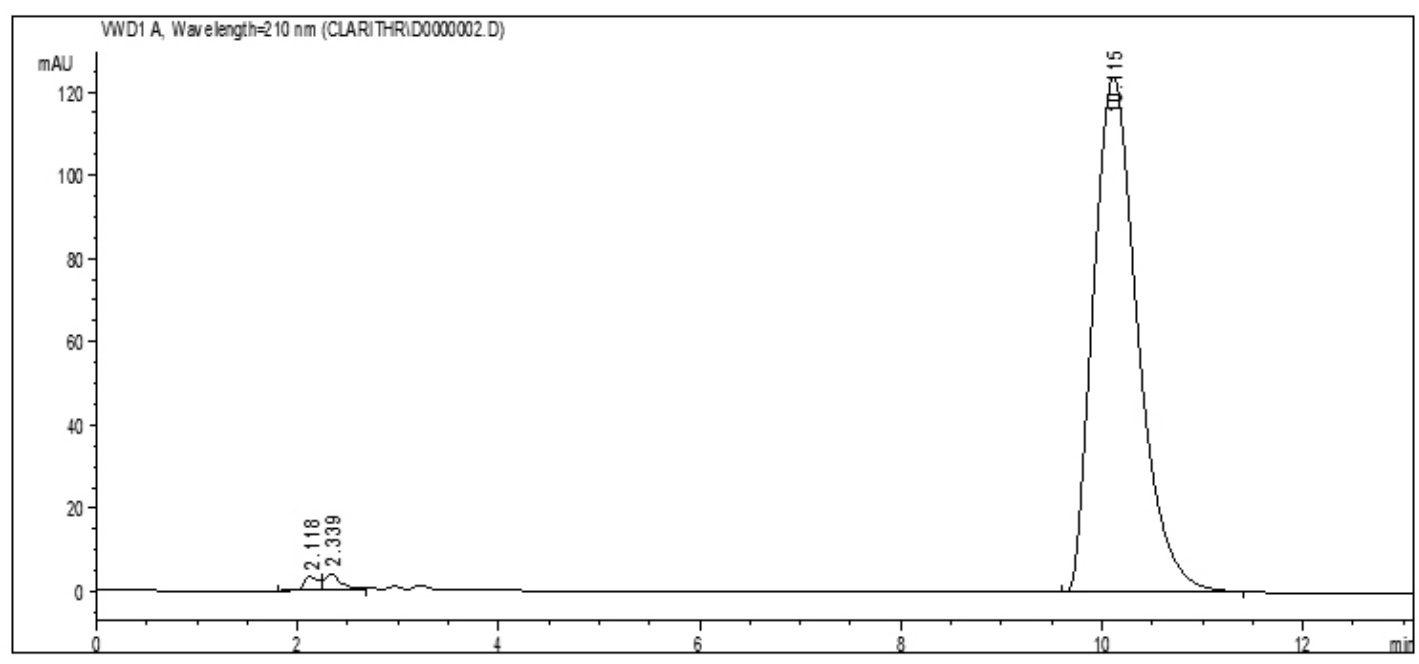

Figure 7: Chromatogram of stress degradation on dry heating.

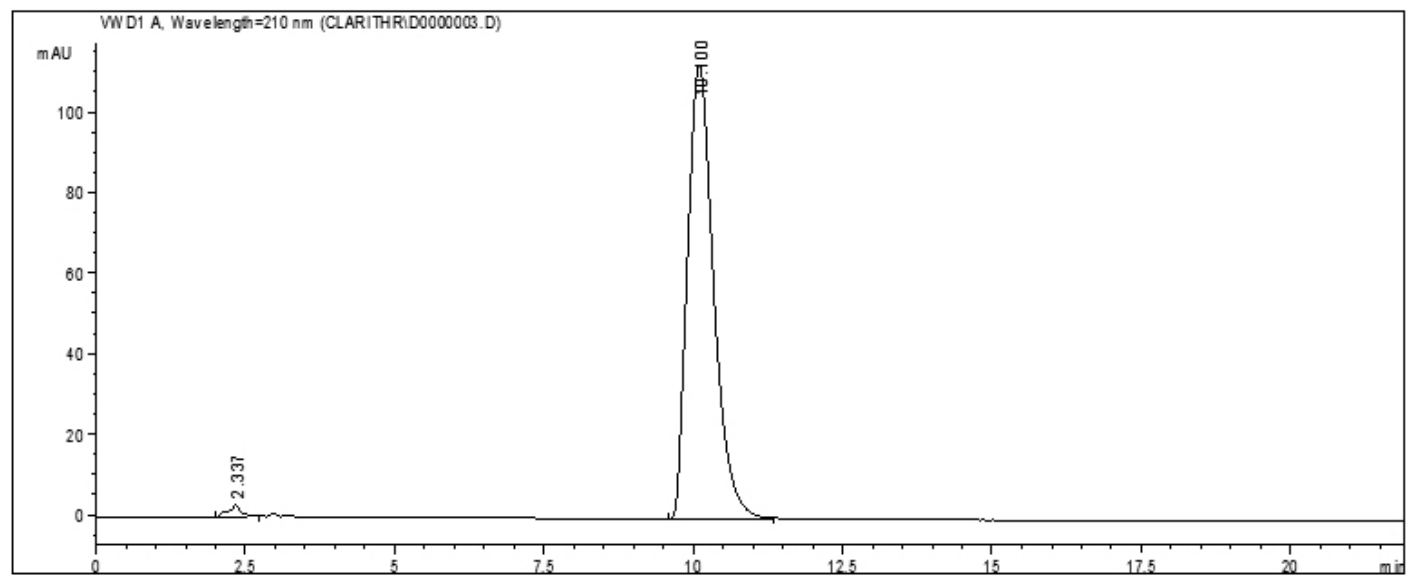

Figure 8: Chromatogram of stress degradation with UV light.

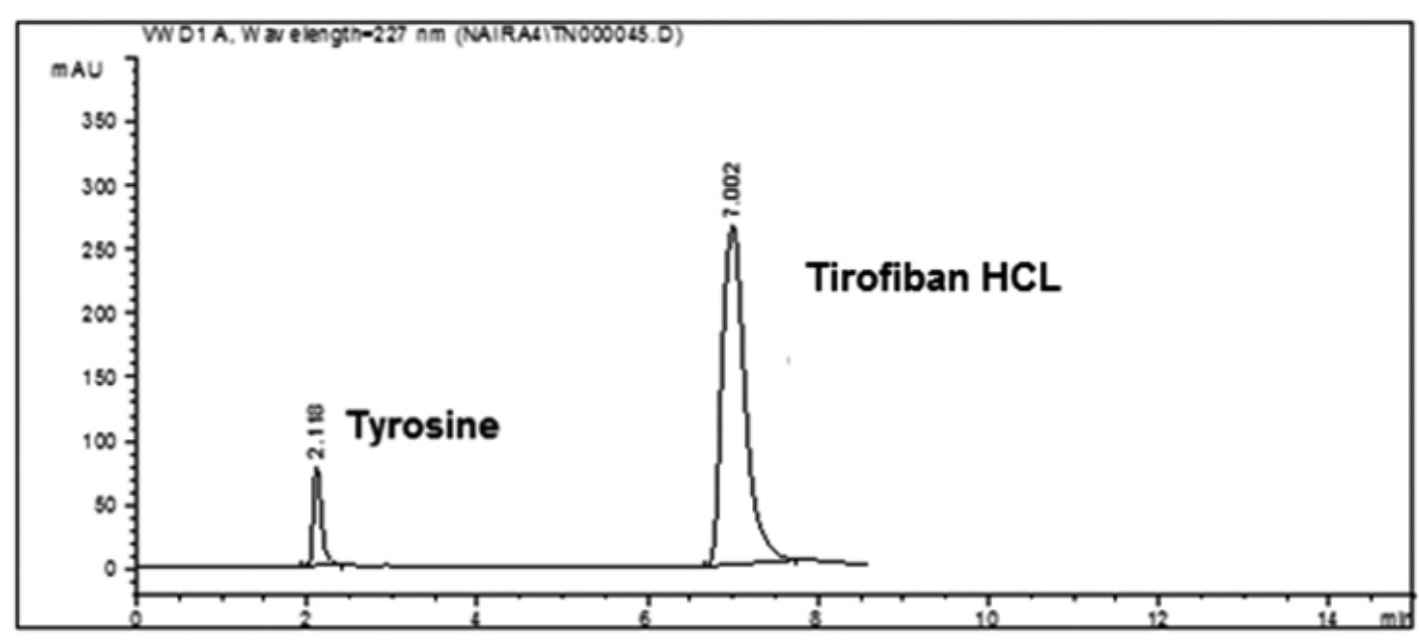

Figure 9: Tirofiban HCL and tyrosine mixture. 


\section{Accuracy}

Accuracy of the chromatographic procedure was calculated as \% recovery \pm SD by analyzing six different concentrations $\left(250\right.$ and $\left.2.5 \mu \mathrm{g} \mathrm{mL}^{-1}\right),(200$ and $\left.10 \mu \mathrm{g} \mathrm{mL}^{-1}\right),\left(150\right.$ and $\left.15 \mu \mathrm{g} \mathrm{mL}^{-1}\right),\left(100\right.$ and $\left.15 \mu \mathrm{g} \mathrm{mL}^{-1}\right),(50$ and 10 $\left.\mu \mathrm{g} \mathrm{mL}^{-1}\right)$ and $\left(40\right.$ and $\left.10 \mu \mathrm{g} \mathrm{mL}^{-1}\right)$ of laboratory prepared mixtures of the drug substances of TIR and TRS, respectively. The concentration of samples employed to perform accuracy were from $40-250 \mu \mathrm{g} \mathrm{mL} \mathrm{m}^{-1}$ of TIR and 2.5-10 $\mu \mathrm{g} \mathrm{mL} \mathrm{m}^{-1}$ of TRS. The results obtained were statistically compared with those obtained by the reported method for TIR (In house specification using HPLC method) [13] and the pharmacopeial method for TRS [14]. The calculated t and F- values [15] were less than the tabulated values. The pharmaceutical dosage form, Aggrastat ${ }^{\circledR}$ intravenous infusion was assayed for the content of TIR using the proposed RP- LC method and the validity of the method was further assessed by applying the standard addition technique. The results are displayed in Table 2.

Precision

Precision was estimated by repeatability, intraday and inter-day precision. The repeatability of the method was assessed by analyzing mixtures of 100-30 and $125-35$ and $150-40 \mu \mathrm{gL}^{-1}$ of TIR and TRS $(\mathrm{n}=9)$ respectively. The values of the precision (\%R.S.D), intra-day and inter-day precision (using 3 different concentrations in triplicates for three consecutive days) for the two analytes are displayed in Table 2 .

Table 2. Results of analytical performance and validation data of the proposed LC method.

\begin{tabular}{|c|c|c|}
\hline Item & TIR & TRS \\
\hline Retention time (min) & $7.01 \pm 0.07$ & $2.19 \pm 0.06$ \\
\hline Wavelength of detection (nm) & 227 & 227 \\
\hline Range of linearity & $10-250 \mu \mathrm{g} \mathrm{mL}-1$ & $1-70 \mu \mathrm{g} \mathrm{ml} \mathrm{m}^{-1}$ \\
\hline $\begin{array}{l}\text { Regression equation* } \\
\qquad \mathrm{y}=\mathrm{b} \mathrm{C} \pm \mathrm{a}\end{array}$ & $\begin{aligned} \text { Area }= & 23.613 \mathrm{C}_{\mu \mathrm{g} \mathrm{mL}}^{-1} \\
& +117.97\end{aligned}$ & $\begin{array}{c}\text { Area }=50.396 \\
\mathrm{C}_{\mu \mathrm{g} \mathrm{mL}}{ }^{-1}+1.0142\end{array}$ \\
\hline Regression coefficient $\left(\mathrm{r}^{2}\right)$ & 0.9991 & 0.999 \\
\hline $\operatorname{LOD}\left(\mu \mathrm{g} \mathrm{mL}^{-1}\right)$ & 1.76 & 0.13 \\
\hline LOQ $\left(\mu \mathrm{g} \mathrm{mL}^{-1}\right)$ & 5.88 & 0.44 \\
\hline $\mathrm{S}_{\mathrm{b}} * *$ & 0.01 & 0.02 \\
\hline $\mathrm{S}_{\mathrm{a}} * *$ & 0.09 & 0.09 \\
\hline Intraday precision \%R.S.D & $0.26-1.68$ & $0.26-1.88$ \\
\hline Interday precision $\%$ R.S.D & $0.6-0.99$ & $0.33-1.76$ \\
\hline \multicolumn{3}{|l|}{ Accuracy ( $\%$ Recovery \pm SD) } \\
\hline $\begin{array}{c}\text { Drug product } \\
\text { Standard added } \\
\text { Drug substance } \\
\text { t-test }(2.31)^{* * *} \\
\text { F- test }(6.39)^{* * *}\end{array}$ & $\begin{array}{c}100.38 \pm 1.21 \\
100.57 \pm 1.28 \\
100.35 \pm 1.13 \\
0.74 \\
1.69\end{array}$ & $\begin{array}{c}100 \overline{15 \pm 0.93} \\
0.09 \\
5.55\end{array}$ \\
\hline
\end{tabular}

$* \mathrm{Y}=$ area under the peak, $\mathrm{b}, \mathrm{a}=$ slope and intercept of regression line and $\mathrm{C}=$ concentration $\left(\mu \mathrm{g} \mathrm{mL}^{-1}\right)$.

** $\mathrm{S}_{\mathrm{b}}$ and $\mathrm{S}_{\mathrm{a}}$ are standard deviations of slope and intercept.

$* * *$ Tabulated values of $\mathrm{t}$ and $\mathrm{F}$ tests of $\mathrm{n}=5$ for both proposed $\mathrm{LC}$ and comparison methods at $\mathrm{P}=0.05$.

\section{Selectivity}

The selectivity of a method is the extent to which it can be used for analysis of particular analyte without interference from other components. In this assay, selectivity was checked by analyzing TIR in laboratory prepared mixtures with TRS. Good resolution and absence of interference between compounds being analyzed are shown in Figure 9.

\section{Robustness}

Robustness was performed by deliberately changing the chromatographic conditions. Variation of the $\mathrm{pH}$ of the mobile phase by \pm 0.2 units, flow rate of the mobile phase by $\pm 0.1 \mathrm{~mL} \mathrm{~min}^{-1}$ and organic strength of the mobile phase by $\pm 2 \%$ were studied. The parameter considered was the resolution factor (R) between the two peaks. These variations did not have significant effect on chromatographic resolution in the proposed LC method and results are given in Table 3.

Table 3. Robustness results for the proposed LC method.

\begin{tabular}{|c|c|}
\hline Factor & Resolution \\
\hline Flow rate & \\
$0.9 \mathrm{ml} / \mathrm{min}$ & 20.44 \\
$1.1 \mathrm{ml} / \mathrm{min}$ & 20.01 \\
\hline Mobile phase ratio & \\
$72: 28$ & 22.66 \\
$68: 32$ & 18.24 \\
\hline $\mathrm{PH}$ & \\
2.8 & 20.11 \\
3.2 & 20.35 \\
\hline
\end{tabular}

Limit of detection and limit of quantification

Limit of detection (LOD) which represents the concentration of analyte at $\mathrm{S} / \mathrm{N}$ ratio of 3 and limit of quantification (LOQ) at $\mathrm{S} / \mathrm{N}$ ratio of 10 were determined experimentally for the proposed method using $\left(1 \mu \mathrm{g} \mathrm{mL}^{-1}\right)$ of each TIR and TRS and results are given in Table 2.

System suitability Tests

According to USP 2016 [15], system suitability tests are an integral part of liquid chromatographic methods in the course of optimizing the conditions of the proposed method. System suitability tests are used to verify that the resolution was adequate for the analysis performed. The parameters of these tests are column efficiency (number of theoretical plates), tailing of chromatographic peak, peak resolution factor, repeatability as \%R.S.D of peak area for six injections and reproducibility of retention as \%R.S.D of retention time. The results of these tests for the proposed method are listed in Table 4.

Table 4. System suitability tests for the proposed LC method.

\begin{tabular}{|c|c|c|}
\hline Item & TIR & TRS \\
\hline $\begin{array}{l}\text { USP plate count }(\mathrm{N}) \\
>1500\end{array}$ & 3369 & 2704 \\
\hline $\begin{array}{l}\text { Resolution (Rs) } \\
>1.5\end{array}$ & 15.11 & - \\
\hline $\begin{array}{l}\text { Tailing Factor }(\mathrm{T}) \\
0.8-1.5\end{array}$ & 1.47 & 1.50 \\
\hline$\underset{>1}{\operatorname{Selectivity}(\alpha)}$ & & \\
\hline $\begin{array}{c}\text { RSD } \% \text { of } 6 \text { injections of } \\
\text { Peak area } \\
\text { Retention time }\end{array}$ & $\begin{array}{l}0.77 \\
1.36\end{array}$ & $\begin{array}{l}1.75 \\
0.11\end{array}$ \\
\hline
\end{tabular}

\section{CONCLUSION}

Stress degradation study on tirofiban hydrochloride provides knowledge about possible partial degradation of the drug. Fortunately, tyrosine was identified by the proposed RP- LC as one of the degradation products.

The proposed LC method proved to be simple, accurate and reproducible for the simultaneous determination of TIR and TRS as a process impurity in a reasonable run time. The method was validated showing satisfactory data for all the method validation parameters tested. The developed method can be conveniently used by quality control laboratories.

\section{REFRENCES}

1. Akl et al., J Chromat Separation Techniq, 4:4, (2013)

2. Alison Brayfield, Martindale, The complete Drug Reference, $38^{\text {th }}$ edn, $\mathrm{P}$ 2098, volume A, (2014).

3. ZHENG Yong-Yong, ZHANG Zi-Xue, HUANG Lei et al, CJPH, 43(6) 408-410, (2012).

4. HUANG Rong-fu, ZHAO Chi, SUN Jun-feng, WEI Qing, J. Cnki china pharmacy, (May 2010). 
5. M. Gandhimathi, Sai Theja Athoti and T.K. Ravi, IAJPR, 3(11): 93109315, (2013)

6. K. Sridevi Ranjitha and A.Lakshmana Rao, IJPCBS, 1(1), 43-47, (2011)

7. Marija, et al. Int J Pharm, 4(4):115-120, (2014).

8. YIN, Yang-jie; QIAO, Lei; ZHANG, Qi-ming, Chinese Journal of Pharmaceutical Analysis, Volume 33, pp. 1012-1015(4), Number 6, (2013).

9. NATARAJ K.S, S.V. SAI KUMAR, N.V.V.S.KALYANI.P AND M. BADRU DUZA, ijpps, ISSN- 0975-1491 Vol 5, Suppl 1, (2013)

10. Ellis JD, Hand EL and Gilbert JD, J Pharm Biomed Anal.,15(5):561-569, (1997).
11. Oertel R, Kohler A, Koste A and Kirch W., J Chromatogr B., 805(1):181$185,(2004)$.

12. The European Agency for The Evaluation of Medical Products. ICH Topic Q2B Note for Guidance on Validation of Analytical Procedures: Methodology CPMP/ICH/281/95 (1996).

13. In-house specification for the analysis of tirofiban, Gland chemical private LTD (Egypt)

14. B.L. Agarwal, Basic statistics, $6^{\text {th }}$ edn, p. 189, 279, (2013).

15. The United States Pharmacopoeia (USP 39), National Formulary (NF 34), Rockville, MD (2016). 